\title{
Microbial colonization and activity in relation to organic carbon in sediments of hypertrophic coastal waters (Nordrügensche Bodden, Southern Baltic Sea)
}

\author{
Marion Köster*, Sven Dahlke, Lutz-Arend Meyer-Reil
}

Institut für Ökologie der Ernst-Moritz-Arndt-Universität Greifswald, Schwedenhagen 6, 18565 Kloster/Hiddensee, Germany

\begin{abstract}
This study investigated the microbial community structure and functioning in relation to properties of dominant sediment types (sand, mud) of hypertrophic inner coastal waters. A transect in the Großer Jasmunder Bodden (inner part of the Nordrügensche Bodden, Southern Baltic Sea), with 6 stations from the shore to the central part was sampled in June 1999. In light-exposed nearshore sandy sediments, microphytobenthos was the driving source for benthic metabolism. Positive relationships between photoautotrophic biomass and available dissolved organic carbon (measured with a microbial biosensor) suggested that the pool of available dissolved organic nutrients was supplied by photosynthesis products of the benthic microalgae. Organic matter produced by these algae was rapidly recycled and led to low standing stocks of organic matter. In contrast, muddy organic-rich accumulation sites in greater water depths with limited or no light were heterotrophically dominated. These sediments retained large amounts of deposited organic matter, especially organic carbon and phosphorus. Intensive microbial degradation of deposited organic matter resulted in enhanced enzymatic activity, and in enhanced concentrations of ammonium and phosphate in porewaters. Our findings revealed that sedimentary bulk parameters such as concentration and degradability of particulate organic carbon as well as microbial biomass and activity depend on mud content in pure sandy sediments (with a mud content $<10 \%$ ), while they remain unchanged in sediments with higher mud content. Carbon-normalized enzymatic activity rates revealed that substrate turnover rates in muddy sediments of hypertrophic waters were relatively low compared to sediments with comparable total organic carbon concentrations in eutrophic waters. These findings imply that the availability of degradable organic matter (accounting only for $<1 \%$ of total organic matter) and probably inorganic nutrients might be of much greater importance in regulating microbial biomass and activity than total organic carbon.
\end{abstract}

KEY WORDS: Sediment characteristics $\cdot$ Sand $\cdot$ Mud $\cdot$ Organic matter $\cdot$ Available dissolved organic carbon $\cdot$ Benthic microbial colonization $\cdot$ Enzymatic degradation activity

\section{INTRODUCTION}

Coastal estuarine sediments are important sites for production and remineralization of organic matter and recycling of nutrients. During the last few decades, increased external and internal inputs of organic matter and inorganic nutrients have resulted in severe eutrophication of coastal waters (e.g. Meyer-Reil 1999). The transformation of organic and inorganic matter depends on sediment properties, the amount of input, the recycling and removal efficiency by biological and physicochemical processes, as well as the hydrodynamical conditions of each estuary (Magalhaes et al. 2002).

The nature of substrata and substrates (e.g. grain size, porosity, quantity and quality of organic matter) significantly affects sedimentary nutrient regimes and benthic microbial colonization (Dale 1974). Generally, sands in coastal environments are organically poor, nonaccumulating sites and have low particulate organic 
carbon and nutrient concentrations. As low organic matter content may be a consequence of rapid and high turnover rates, sandy sediments could considerably contribute to the mineralization of organic carbon and recycling of nutrients (Hüttel \& Rusch 2000, Hüttel 2002, Precht \& Hüttel 2003). Muddy sediments, however, are generally characterized by high concentrations of particulate organic matter, strong gradients of inorganic and organic nutrient concentrations and elevated nutrient fluxes at the sediment-water interface (Reay et al. 1995, Grenz et al. 2000).

The functioning and activity of benthic communities strongly influence nutrient cycles. As demonstrated in several studies (e.g. Reay et al. 1995, Sundbäck et al. 2000), microphytobenthos exerts a significant effect on the supply of oxygen and nutrients at the sediment-water interface in sandy sediments of shallow waters. Via photosynthesis, microphytobenthos contributes to the oxygenation of sediments (Baillie 1986); via assimilation, benthic microalgae can remove significant amounts of inorganic nutrients from the overlying water and may function as a sink for inorganic nutrients (Sundbäck 1994, Anderson et al. 2003). Simultaneously, benthic microalgae excrete the surplus of their photosynthetic products, which can serve as a carbon source for heterotrophic microorganisms as well as for meiofauna and macrofauna (Miller et al. 1996, Smith \& Underwood 2000), thus causing a tight coupling between autotrophy and heterotrophy. Faunal activity, especially irrigation of infauna, significantly influences nutrient cycles, stimulating decomposition processes and removal of porewater solutes (Hüttel 1988, Kristensen 1988, Kitlar 1991, Banta et al. 1999, Christensen et al. 2000). Furthermore, faunal activity enhances sediment mixing and introduces oxygenated waters to deeper sediment layers (Glud et al. 2003).

The object of the present study was to investigate the structure and functioning of microbial communities in dominant sediment types (sand, mud) of a hypertrophic coastal inlet in the southern Baltic Sea. We addressed the following question: How do sediments different in bulk organic matter characteristics (percentage of the sediment fraction $<63 \mu \mathrm{m}$, particulate organic matter, and porewater constituents) contribute to organic matter turnover in relation to benthic microbial colonization and activity? In particular, the lability of organic matter was assessed by different indicators of degradability and related to microbial metabolism. The quantification of readily available dissolved organic carbon (ADOC) measured with a microbial biosensor was seen as essential to improve the understanding of nutrient fluxes through microbial communities (Köster \& Meyer-Reil 2001). Interactions and relationships between sedimentary organic matter, microbial biomass and activity were of special interest to characterize the functioning of microbial communities in sediments of highly eutrophicated waters. We compared data of this study with data obtained from an earlier study performed in sediments of eutrophic waters (cf. Köster \& Meyer-Reil 2001) to estimate how a different degree of eutrophication might influence size and composition of carbon pools as well as the functioning of benthic microbial communities.

\section{MATERIALS AND METHODS}

Study area. Investigations were conducted in the Großer Jasmunder Bodden (GJB), a coastal hypertrophic inlet in the inner part of the Nordrügensche Bodden (Southern Baltic Sea; Hübel et al. 1998). The GJB has a surface area of $58.6 \mathrm{~km}^{2}$, an average depth of $5.3 \mathrm{~m}$, and a maximal depth of $10.3 \mathrm{~m}$ (Aurada 2000). While more than $90 \%$ of the sediments consists of mud prevailing in the deeper regions in the central part, the GJB also provides shallow sandy areas with water depths less than $2 \mathrm{~m}$ (S. Dahlke pers. comm.). The GJB is characterized by low water exchange with the Baltic Sea, low salinity, and high nutrient loads sustaining intensive phytoplankton development and high primary production (Köster et al. 1997, Hübel et al. 1998). Due to sedimentation of high amounts of phytodetritus, large amounts of organic and inorganic nutrients accumulated in these sediments over years (Meyer-Reil 1999).

We sampled 6 stations along a transect from the shore to the central part of the inlet from June 16 to June 24, 1999. Stns 3 and 4 were located 0.2 and $0.6 \mathrm{~km}$ offshore, where water depths were 0.5 and $2.0 \mathrm{~m}$, respectively; Stns 5 and 6 (1.5 and $2.2 \mathrm{~km}$ off-

Table 1. Locations, water depths, oxygen saturation of the bottom water, and sediment type (surface sediment) of the 6 stations sampled in the Großer Jasmunder Bodden (GJB) in June 1999. Order of stations corresponds to their location along transect from shallow to deep waters

\begin{tabular}{|c|c|c|c|c|}
\hline Stn & $\begin{array}{l}\text { Latitude, } \\
\text { Longitude }\end{array}$ & $\begin{array}{c}\text { Water } \\
\text { depth (m) }\end{array}$ & $\begin{array}{c}\text { Oxygen (\% atm } \\
\text { saturation) }\end{array}$ & $\begin{array}{l}\text { Sediment } \\
\text { type }\end{array}$ \\
\hline 3 & $\begin{array}{l}54^{\circ} 31.894^{\prime} \mathrm{N}, \\
13^{\circ} 30.311^{\prime} \mathrm{E}\end{array}$ & 0.5 & 108 & Sand \\
\hline 4 & $\begin{array}{l}54^{\circ} 31.801^{\prime} \mathrm{N}, \\
13^{\circ} 30.070^{\prime} \mathrm{E}\end{array}$ & 2.0 & 109 & Sand \\
\hline 5 & $\begin{array}{l}54^{\circ} 31.698^{\prime} \mathrm{N}, \\
13^{\circ} 29.130^{\prime} \mathrm{E}\end{array}$ & 6.6 & 103 & Sand \\
\hline 6 & $\begin{array}{l}54^{\circ} 31.645^{\prime} \mathrm{N}, \\
13^{\circ} 28.751^{\prime} \mathrm{E}\end{array}$ & 7.0 & 102 & $\begin{array}{l}\text { Slightly muddy } \\
\text { sand }\end{array}$ \\
\hline 2 & $\begin{array}{l}54^{\circ} 31.568^{\prime} \mathrm{N}, \\
13^{\circ} 28.063^{\prime} \mathrm{E}\end{array}$ & 7.0 & 80 & Mud \\
\hline 1 & $\begin{array}{l}54^{\circ} 31.551^{\prime} \mathrm{N}, \\
13^{\circ} 27.594^{\prime} \mathrm{E}\end{array}$ & 7.0 & 96 & Mud \\
\hline
\end{tabular}




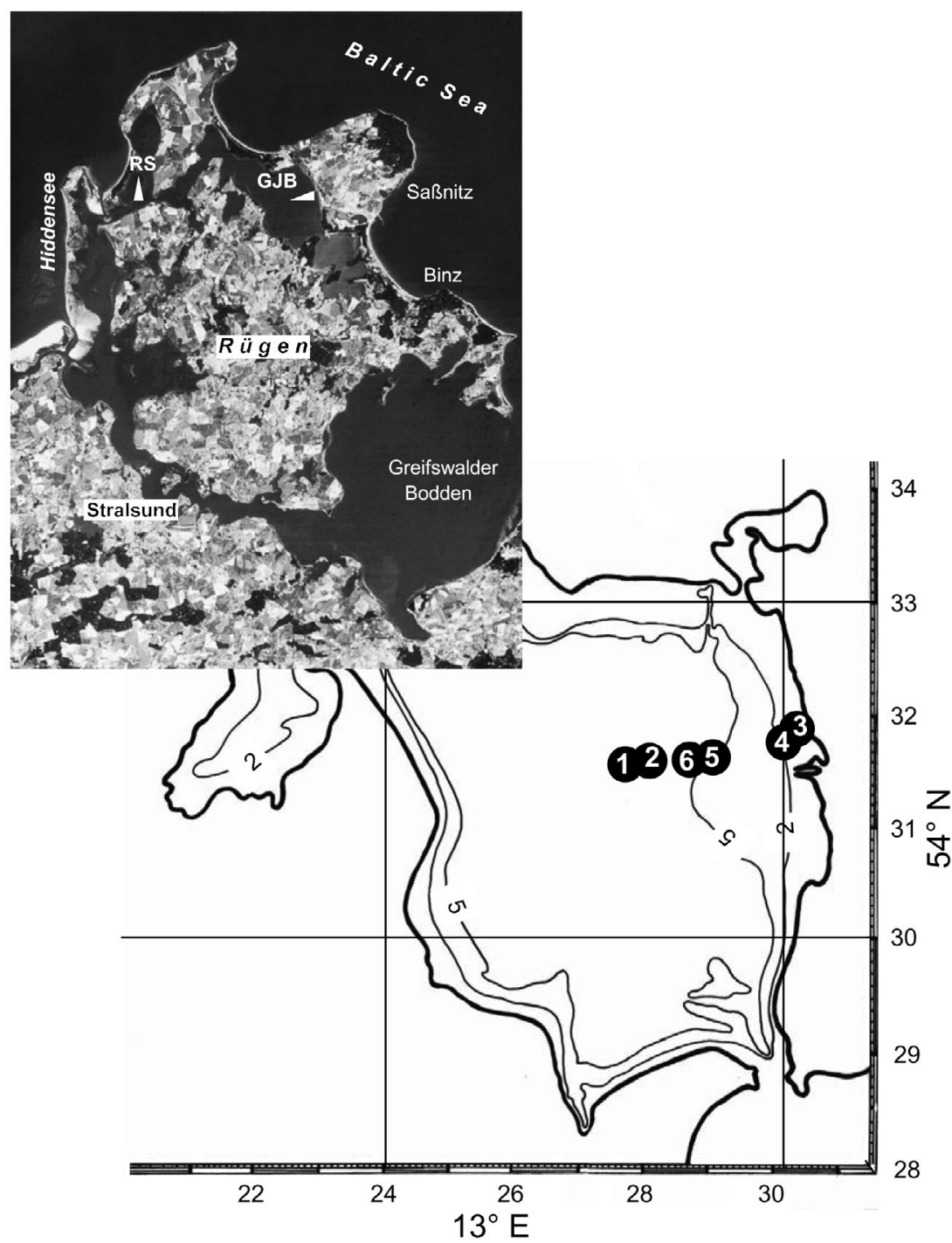

Fig. 1. Großer Jasmunder Bodden (GJB), showing positions of 6 sampling stations. Stns 3, 4, 5 and 6 comprise sandy sediments, Stns 1 and 2 muddy sediments. In inset, white arrowheads indicate location of the GJB and RS (Rassower Strom) in the Nordrügensche Bodden, southern Baltic Sea, Germany (the latter was investigated in an earlier study: Köster \& Meyer-Reil 2001); contour lines show 2 and $5 \mathrm{~m}$ depths

2002). We sliced 3 sediment cores from each sampling site into distinct horizons ( 0 to 1,1 to 2,2 to 3,4 to 5,6 to 7 , and 9 to $10 \mathrm{~cm}$ ). The material from corresponding horizons was combined and thoroughly mixed for analyses of various geochemical and microbiological parameters. For macrofauna analyses, 6 additional sediment cores were taken at each sampling station.

Sediment properties. Sediment types were identified according to a classification scheme based on the percentage of the sediment fraction $<63 \mu \mathrm{m}$ to total sediment dry weight (Flemming 2000). The contribution of the sediment fraction $<63 \mu \mathrm{m}$ to total dry mass of sediment was defined as mud content. Water content (3 parallels of $2 \mathrm{~cm}^{3}$ of sediment) was determined by weight loss at $105^{\circ} \mathrm{C}$ after $24 \mathrm{~h}$. Total organic carbon and nitrogen were determined in dried, homogenized and HCl-treated sediments after combustion at $950^{\circ} \mathrm{C}$ in an Heraeus vario-el CHN-analyzer (Köster et al. 1997). Total and organic phosphorus were analyzed using the ignition method of Andersen (1976) modified as described by Köster \& Meyer-Reil (2001). Organic phosphorus was calculated as the difference between total and inorganic phosphorus. All fractions of the sedimentary organic and inorganic matter were quantified in terms of concentration $\left(\mathrm{mg} \mathrm{cm} \mathrm{cm}^{-3}\right.$ wet sediment) to account for differences in dry bulk densities of the sediments (see Bird \& Duarte 1989, Flemming \& Delafontaine 2000).

Porewater constituents. Porewater was gained by centrifugation (15 min, $2^{\circ} \mathrm{C}, 2772 \times g$ ) and immediately filtered through GF/F filters (Whatman). For dissolved organic carbon (DOC) analyses,

shore) were located on the slope in a water depth of 6.6 and $7.0 \mathrm{~m}$, respectively (Fig. 1, Table 1). Muddy sampling sites (Stns 1 and 2; 3.1 and $2.8 \mathrm{~km}$ offshore) were located in the central part of the inlet. During the sampling period, salinity ranged between 6.8 and 6.9 , temperature and oxygen concentration above the sediment surface were between 17.3 and $18.5^{\circ} \mathrm{C}$ and between 7.3 and $9.7 \mathrm{mg} \mathrm{l}^{-1}$, respectively.

At the shallow-water stations, sediments were collected in plexiglass tubes (length of $30 \mathrm{~cm}$, inner diameter of $10 \mathrm{~cm}$ ) by divers. At deeper locations, sediments were sampled with a multiple corer (Black et al. bottom water and porewater samples were additionally filtered through cellulose nitrate membrane filters (pore size $0.2 \mu \mathrm{m}$ ) and stored in glass ampoules at $-20^{\circ} \mathrm{C}$ until processing. DOC was measured by hightemperature catalytic oxidation at $680^{\circ} \mathrm{C}$ in a Shimadzu TOC-5050 analyzer (Cauwet 1999). ADOC was measured with a microbial biosensor consisting of a Clark-type oxygen microelectrode with immobilized bacteria at the tip (Neudörfer \& Meyer-Reil 1997). The microbial biosensor responds to ADOC by bacterial oxygen consumption calculated from the linear decrease of the time-dependent current signal of the 
electrode. Relative amounts of ADOC were measured as glucose equivalents in oxygen-saturated porewaters filtered through $0.2 \mu \mathrm{m}$ membrane filters (Köster \& Meyer-Reil 2001). Concentrations of ammonium, phosphate and silicate in GF/F-filtered bottom water and porewater were quantified spectrophotometrically according to standard procedures of Grasshoff et al. (1999). Nitrate and nitrite concentrations were determined by ion chromatography at a wavelength of $220 \mathrm{~nm}$. Microprofiles of oxygen concentrations were measured by Clark-type oxygen microelectrodes (Revsbech 1989) in sediments incubated in the dark at close to in situ conditions. The oxygen sensor tip had an inner diameter of approximately $6 \mu \mathrm{m}$, a $t_{90}$ response time of $<1 \mathrm{~s}$, and was calibrated in oxygensaturated bottom water $(100 \%$ air saturation $)$ and anoxic sediment ( $0 \%$ oxygen).

Microbial biomass and enzymatic activity. For the determination of microbial biomass, different cell constituents were assayed as proxy parameters in selected sediment horizons ( 0 to 1,4 to 5 , and 9 to $10 \mathrm{~cm}$ ). Total microbial biomass (including heterotrophic and autotrophic organisms) was estimated from the spectrophotometric determination of phospholipids (Findlay et al. 1989). For the estimation of photoautotrophic biomass and its degradation products, chlorophyll a (chl a) and pheopigment analyses were performed according to the guidelines of HELCOM (1988). Chl a concentrations were converted to autotrophic biomass carbon assuming a conversion factor of 40 proposed for microphytobenthos (Cammen 1991). Bacterial cells were stained with acridine orange and enumerated using epifluorescence microscopy (Meyer-Reil 1983). Bacterial biomass was calculated by multiplying bacterial abundance by sediment-specific bacterial carbon contents of $16 \mathrm{fg} \mathrm{C}^{\mathrm{C}} \mathrm{cell}^{-1}$ for sandy sediments and $11 \mathrm{fg} \mathrm{C}$ cell $^{-1}$ for muddy coastal sediments (Meyer-Reil 1993).

Microbial enzymatic decomposition was analyzed for selected sediment horizons ( 0 to 1,4 to 5 , and 9 to $10 \mathrm{~cm}$ ) according to Köster et al. (1997). Aliquots of $5 \mathrm{~cm}^{3}$ of sandy sediments were diluted 1:10 with $\mathrm{KH}_{2} \mathrm{PO}_{4} / \mathrm{Na}_{2} \mathrm{HPO}_{4}$ buffer ( $\mathrm{pH}$ 7.8), and equal aliquots of muddy sediments were diluted 1:20. Two $\mathrm{ml}$ of sediment suspension ( 3 parallels) were supplied with each $40 \mu \mathrm{l}$ of various model substrates at saturation level. Fluorescein diacetate (FDA) was used to estimate esterase activity. Methylumbelliferyl(MUF)- $\beta$-D-glucoside and MUF- $\alpha$-D-glucoside served as substrates for detecting the enzymatic degradation of relatively slowly degradable carbohydrates (cellulose) and relatively labile carbohydrates (starch) indicated by $\beta$-D-glucosidase activity and $\alpha$-D-glucosidase activity, respectively. Ratios of MUF- $\beta$-D-glucosidase activity and MUF- $\alpha$-D-glucosidase activity were used as an indicator for the grade of organic matter decomposi- tion. The release of the fluorescent dyes fluorescein and methylumbelliferone was analyzed spectrofluorometrically at a wavelength of $370 \mathrm{~nm}$ excitation and $410 \mathrm{~nm}$ emission, and at a wavelength of $365 \mathrm{~nm}$ excitation and $445 \mathrm{~nm}$ emission, respectively. Enzymatic activity rates were calculated from the linear part of time-dependent activity curves.

To consider differences in dry bulk densities of sediments, concentrations of cells constituents, bacterial numbers and enzymatic activity rates were given $\mathrm{cm}^{-3}$ of wet sediment.

Macrofaunal colonization. For macrofauna analyses, the upper $10 \mathrm{~cm}$ of 6 sediment cores sampled at each station were separated and sieved through a sieve with a mesh size of $0.5 \mathrm{~mm}$. Macrofauna species were determined and quantified using a stereo-microscope (Nikon SMZ 1000).

Statistics. A Kruskal-Wallis test (non-parametric analysis of variance by ranks) was applied, followed by a multiple comparison test in case the null hypothesis was rejected that values at all stations studied were identical (Conover 1980).

\section{RESULTS}

\section{Sediment properties}

According to the sediment classification of Flemming (2000), nearshore shallow-water sediments of the GJB (Stns 3 and 4) were characterized as pure sand with low mud content (sediment fraction $<63 \mu \mathrm{m}$ was less than $1 \%)$, low water content $(<27 \%)$, high dry bulk density (1.2 to $1.4 \mathrm{~g} \mathrm{~cm}^{-3}$ ) and low organic carbon concentrations (2.8 to $3.3 \mathrm{mg} \mathrm{cm}^{-3}$; Fig. 2). Stn 5, located in deeper waters on the slope represented sand (sediment fraction $<63 \mu \mathrm{m}$ less than $5 \%$ ), with approximately 2 to 3 times higher organic carbon concentrations than those measured in shallow-water sand sediments. Sediments located at the base of the slope (Stn 6) had a $5 \mathrm{~cm}$ thick sand layer sublayered by mud, with both sediment layers being extremely enriched in organic carbon (13.4 to $21.5 \mathrm{mg} \mathrm{cm}^{-3}$ ). Sediments of the central part (Stns 1 and 2) of the GJB were characterized by muddy sediments with high mud content (sediment fraction $<63 \mu \mathrm{m}$ varied between 71 and $89 \%$ ), high water content $(>84 \%)$, low dry bulk density (0.1 to $0.2 \mathrm{~g} \mathrm{~cm}^{-3}$ ), and high organic carbon concentrations increasing from $8.3 \mathrm{mg} \mathrm{cm}^{-3}$ at the sediment surface to $14.4 \mathrm{mg} \mathrm{cm}^{-3}$ in deeper horizons. A Kruskal-Wallis test accompanied by a multiple comparison test revealed that organic carbon concentrations in sediments on the slope and in the central part of the GJB (Stns 1,2 and 6) were significantly higher than in sediments of the shallow-water Stns 3 and $4(p<0.05)$. Molar carbon (C) 

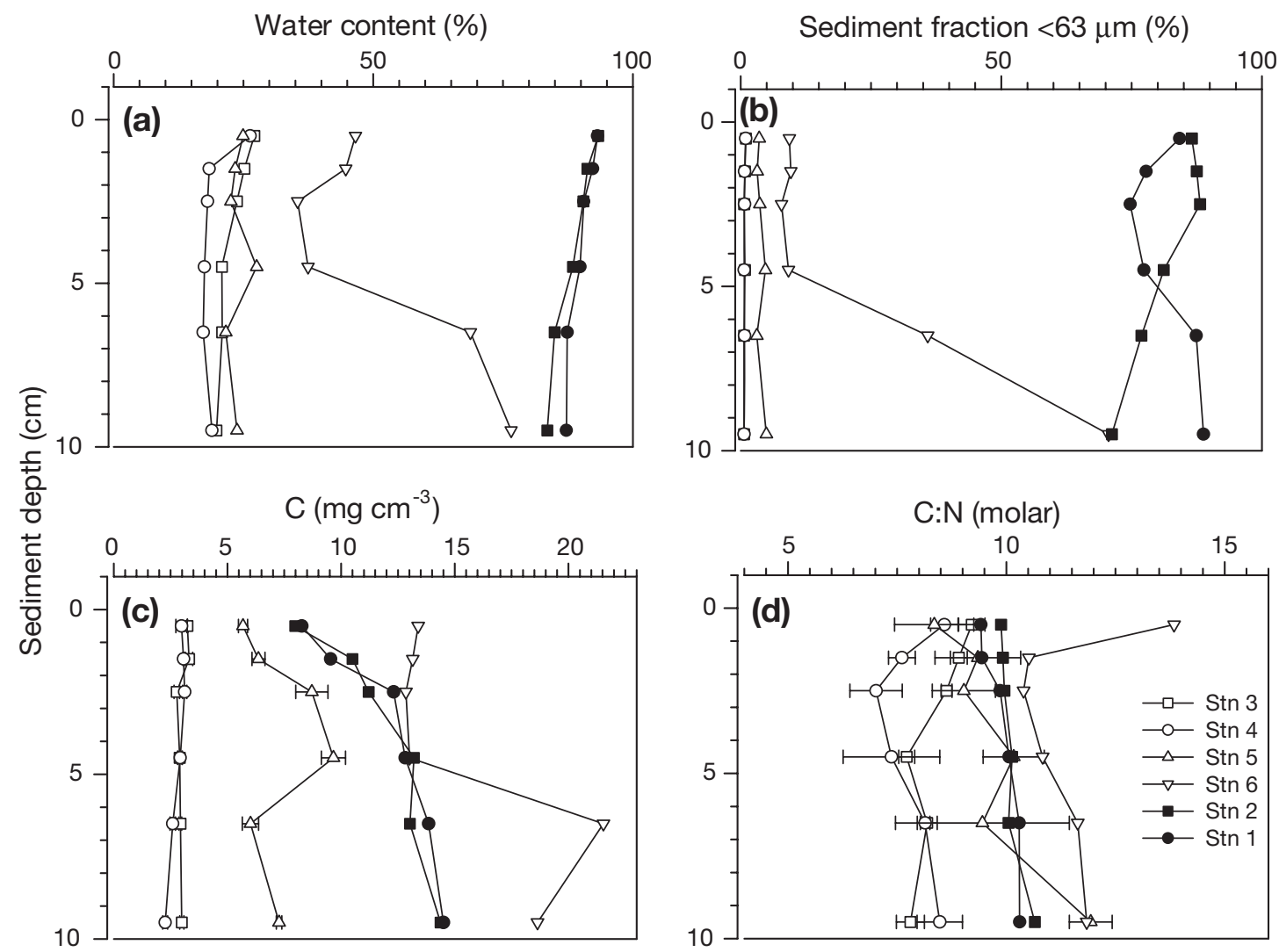

Fig. 2. Sediment profiles of (a) water content, (b) mud content expressed as percentage of sediment fraction $<63 \mu m_{i}$, (c) organic carbon concentration $\mathrm{cm}^{-3}$ of sediment, and (d) molar C:N ratios for 6 stations sampled in the GJB. Error bars in (c) and (d): standard deviations ( $\mathrm{n}=3$ to 6 ); open and filled symbols: sandy and muddy sediments, respectively

to nitrogen $(\mathrm{N})$ ratios ranged from 7.0 to 13.8 at the 6 sampling stations. $\mathrm{C}: \mathrm{N}$ ratios generally increased from sandy to muddy sediments. C:N values measured at Stns 3 and 4 were significantly lower than those at Stns 1, 2 and 6 (Kruskal-Wallis test; $\mathrm{p}<0.05$ ). Increasing $\mathrm{C}: \mathrm{N}$ ratios were accompanied by increases in the percentage of pheopigments to total pigments (chl a plus pheopigments). Highest $\mathrm{C}: \mathrm{N}$ values indicating highly degraded organic matter were found in sandy surface sediments of Stn 6 located at the base of the slope.

Total phosphorus concentrations analyzed for selected horizons increased from 18 to $100 \mu \mathrm{g} \mathrm{cm}^{-3}$ in shallow-water sandy sediments to 108 to $192 \mu \mathrm{g} \mathrm{cm}^{-3}$ in deeper water muddy sediments of the central GJB (Fig. 3a). A Kruskal-Wallis test revealed that total phosphorus concentrations at Stns 3 and 4 were significantly lower than at Stns 1 and $2(p<0.05)$. The sandy sediments were characterized by a strong increase in total phosphorus with increasing sediment depth. In muddy sediments, maximal values of total phosphorus were found in subsurface horizons at depths between 4 and $5 \mathrm{~cm}$. Organic phosphorus made up a large portion of total phosphorus (8 to $55 \%$ in sandy sediments, and 45 to $63 \%$ in muddy sediments). In all sediments, phosphorus deficiency led to N:P values 2 to 15 times higher than the Redfield ratio (Fig. 3b). Muddy sediments had lower N:P ratios and higher $\mathrm{C}: \mathrm{N}$ ratios than sandy sediments, pointing to a relative accumulation of phosphorus and carbon in organic-rich sediments (cf. Fig. 3 with Fig. 2d).

\section{Porewater constituents}

DOC concentrations in porewaters ranged from 8.2 to $29.8 \mu \mathrm{g} \mathrm{cm}^{-3}$ of sediment (Fig. $4 \mathrm{a}, \mathrm{b}$ ). In sandy sediments, DOC contributed between 0.2 and $0.9 \%$ of total organic carbon (TOC), while in muddy sediments DOC contribution was less than $0.2 \%$. ADOC concentrations (Fig. 4c,d) varied between $<0.1$ and $8.0 \mu \mathrm{g} \mathrm{cm}^{-3}$. They were 10 to $42 \%$ of DOC in sandy sediments (Stns 3, 4 and 5), 0 to $9 \%$ of DOC in sand-overlaid muddy sediments (Stn 6), and $<5 \%$ of DOC in muddy sediments (Stn 2). A Kruskal-Wallis test accompanied by a multiple comparison test revealed that ADOC concentrations at Stns 3, 4 and 5 were significantly higher than at Stns 2 and $6(\mathrm{p}<0.05)$. ADOC data for Stn 1 are not available due to methodological problems. 

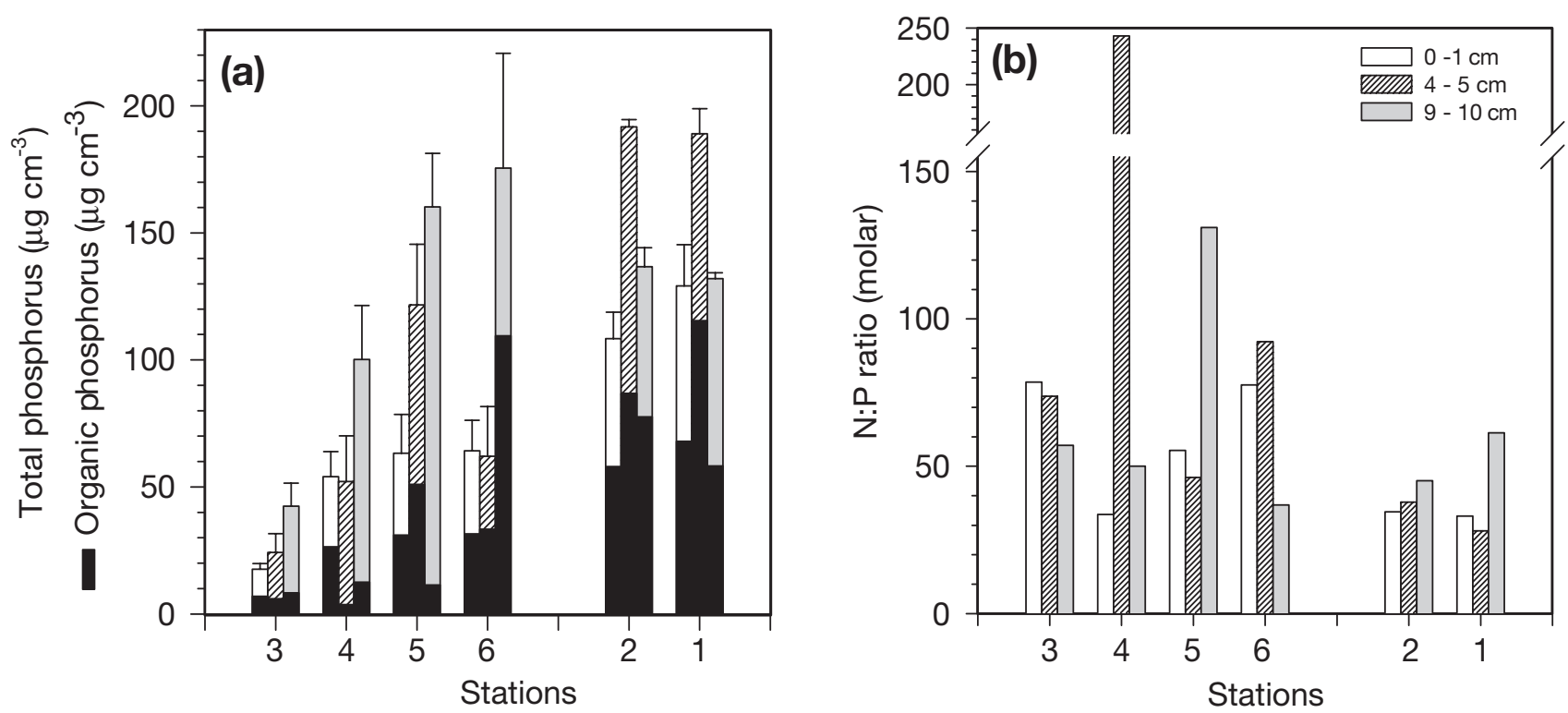

Fig. 3. (a) Total and organic phosphorus concentrations, and (b) molar nitrogen to phosphorus ratios in selected sediment horizons of 6 stations sampled in the GJB. Error bars in $(a)$ : standard deviations $(n=6)$ of total phosphorus concentrations for whole column; black partions of histograms show percentage organic phosphorus

Penetration depths of oxygen were tentatively higher in sandy sediments (3.0 to $3.7 \mathrm{~mm}$ ) than in muddy sediments (2.0 to $2.2 \mathrm{~mm}$; Fig. 5a,b). Nitrate concentrations ranged from 0 to $0.9 \mathrm{nmol} \mathrm{cm}^{-3}$ of sediment; slightly enhanced concentrations were detected in the uppermost muddy sediments of Stn 2 (Fig. 5c). In muddy sediments (Stns 1 and 2), nitrate was almost completely depleted below the sediment surface, whereas in the sandy sediments of Stns 4, 5 and 6 nitrate penetration reached a depth of up to $10 \mathrm{~cm}$. Maxima of nitrate concentrations of up to $2.2 \mathrm{nmol} \mathrm{cm} \mathrm{cm}^{-3}$ were found in the bottom water of the muddy sites (Stns 1 and 2). Concomitant with the general decrease in nitrate with increasing depth was an increase in ammonium and phosphate concentration (Fig. 5d,e). Ammonium concentrations ranged from 5 to 219

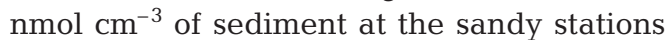
to 57 to $360 \mathrm{nmol} \mathrm{cm}{ }^{-3}$ in the muddy sediments. Phosphate concentrations were relatively low in sandy sediments of Stns 3, 4, 5 and $6\left(0.2\right.$ to $\left.7.7 \mathrm{nmol} \mathrm{cm}^{-3}\right)$, whereas concentrations increased steeply to values of up to $72 \mathrm{nmol} \mathrm{cm}^{-3}$ in deeper layers of muddy sediments (Stns 1 and 2). Porewater profiles of silicate (Fig. 5f) generally followed those of ammonium and phosphate.

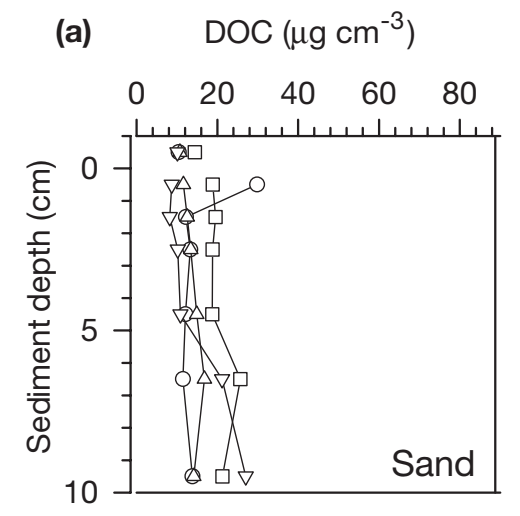

(b) $\quad \mathrm{DOC}\left(\mu \mathrm{g} \mathrm{cm}^{-3}\right)$
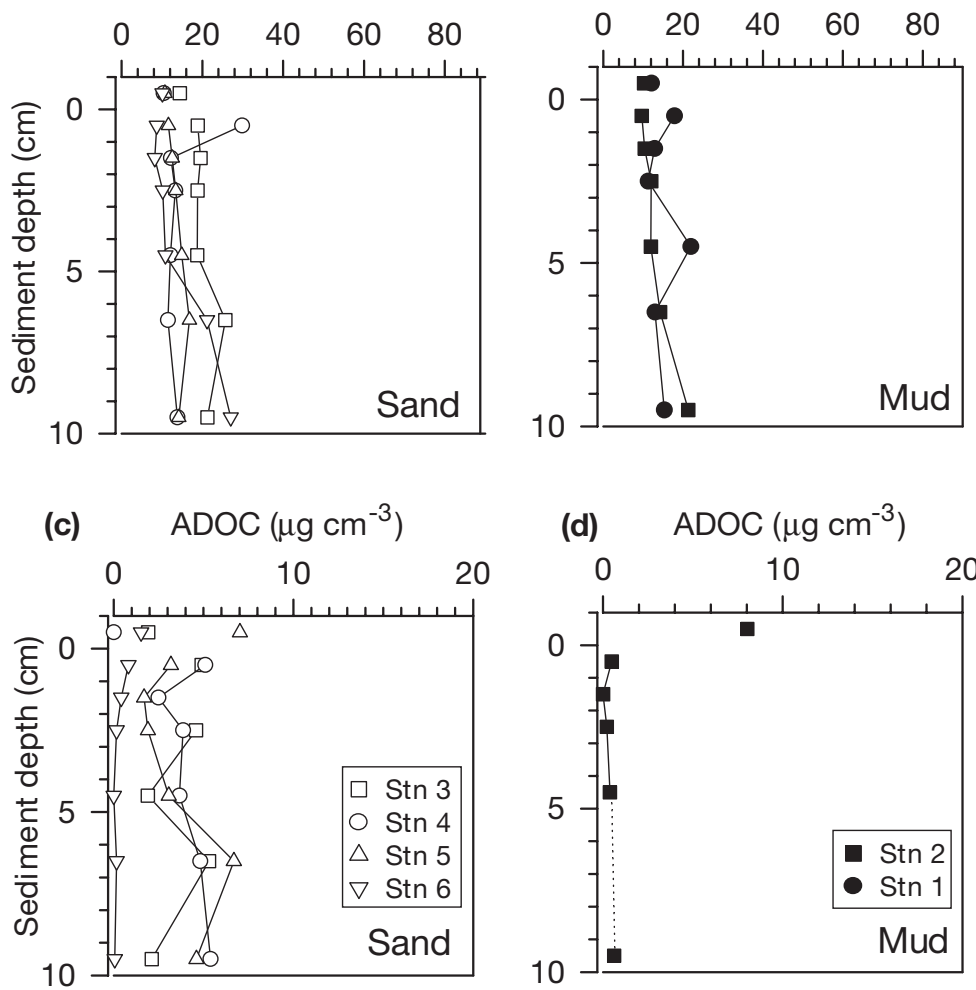

Fig. 4. Sediment profiles of $(a, b)$ dissolved organic carbon (DOC) and $(\mathrm{c}, \mathrm{d})$ available dissolved organic carbon (ADOC) of 6 stations sampled in the GJB. Open and filled symbols: sandy and muddy sediments, respectively 

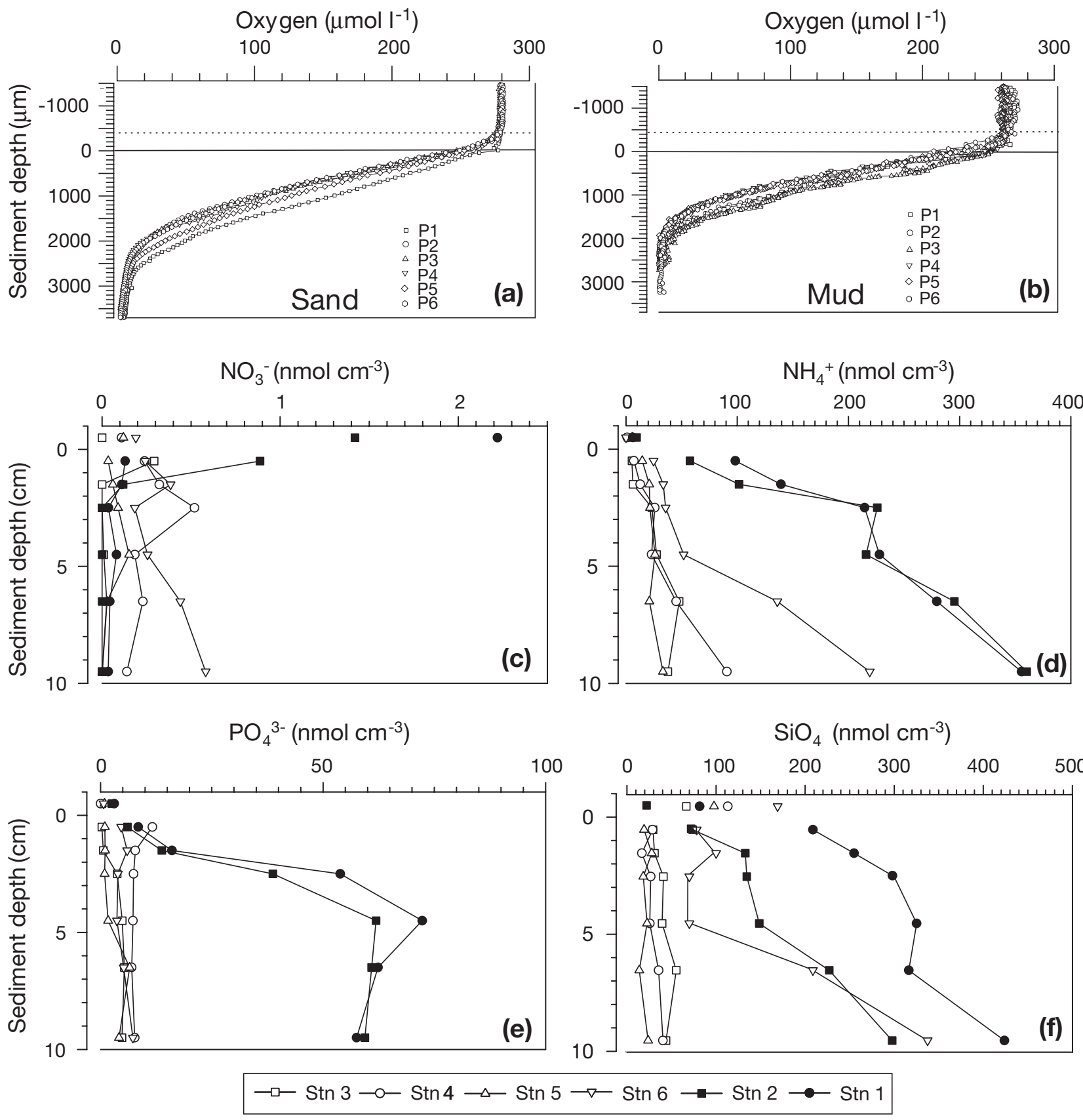

Fig. 5. (a,b) Oxygen distribution measured by microelectrodes in (a) sandy (Stn 4) and (b) muddy (Stn 1) sediments of the GJB, showing characteristic oxygen microprofiles (P1 to P6); continuous line represents sediment surface, dotted line location of diffusive benthic boundary layer. (c to f) Porewater profiles of nitrate, ammonium, ortho-phosphate, and silicate for all 6 stations sampled; means of 3 parallel measurements; open and filled symbols: sandy and muddy sediments, respectively

Values increased with increasing sediment depth, maximal values of 69 to $423 \mathrm{nmol} \mathrm{cm}{ }^{-3}$ were associated with deeper muddy sites (Stns 6, 2, and 1), while tentatively lower concentrations of 17 to 55 $\mathrm{nmol} \mathrm{cm}{ }^{-3}$ were found in sandy sediments of Stns 3, 4 and 5 .

\section{Benthic community}

In the sandy sediments of Stns 3, 4, 5 and 6, the number of macrofauna species varied between 8 and 12 . Extremely high abundances were found for juvenile polychaetes Marenzelleria viridis and Hediste diversi- 
Color (785 to 2907 and 552 to 679 ind. $\mathrm{m}^{-2}$; respectively; Table 2) at these sites. Additionally, adult polychaetes (M. viridis, H. diversicolor), oligochaetes, juvenile mussels (Arenomya arenaria), snails (Hydrobia ulvae) and isopods (Cyathura carinata; Corophium volutator) inhabited these sediments. Digital photographs of sandy shallow-water surface sediments (Stns 3 and 4) documented a dense colonization by microphytobenthos and a sparse occurrence of Zannichellia sp. At muddy sites (Stns 1 and 2), the number of species was reduced to 4-6. Relatively high values of macrofauna abundance in these sediments were caused by the presence of numerous larvae of chironomids (2292 to 10950 ind. $\mathrm{m}^{-2}$ ) accounting for $88 \%$ (Stn 1) and 96\% (Stn 2), respectively, of the total macrofauna.

The structure of the benthic microbial community at the 6 sampling sites was derived from analyses of the proxy parameters phospholipids, chl $a$, and total bacterial number used to estimate total microbial, photoautotrophic, and bacterial biomass (Fig. 6). Phospholipid concentrations increased markedly from shal-

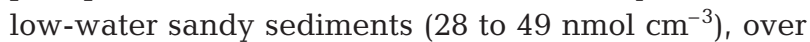
sandy sediments located in deeper water depths (32 to

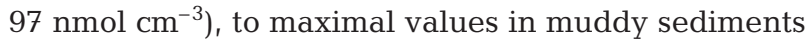
of the central GJB (62 to $102 \mathrm{nmol} \mathrm{cm}^{-3}$ ). A KruskalWallis test accompanied by a multiple comparison test revealed that concentrations of phospholipids at Stns 1

Table 2. Mean abundance (ind. $\mathrm{m}^{-2}$; average of 6 individual sediment cores sampled at each station) of macrofauna taxa collected at 6 stations sampled in the GJB. Taxonomic determination of oligochaetes was not performed. juv.: juvenile; -: absent

\begin{tabular}{|c|c|c|c|c|c|c|}
\hline Taxon & 3 & 4 & 5 & 6 & 2 & 1 \\
\hline Oligochaeta & 233 & 4011 & 85 & 127 & 340 & - \\
\hline \multicolumn{7}{|l|}{ Polychaeta } \\
\hline Marenzelleria viridis & 318 & 106 & 870 & 170 & - & 42 \\
\hline Marenzelleria viridis (juv.) & 785 & 2377 & 2907 & 2228 & - & - \\
\hline Hediste diversicolor & 85 & 42 & 21 & - & - & - \\
\hline Hediste diversicolor (juv.) & 552 & 679 & 85 & - & - & - \\
\hline Streblospio shrubsolii & 42 & - & - & - & - & - \\
\hline Pygospio elegans & - & 42 & 64 & - & - & - \\
\hline Alkmaria romijni & - & - & 85 & - & - & - \\
\hline \multicolumn{7}{|l|}{ Mollusca } \\
\hline Macoma balthica & 21 & - & 212 & 42 & 21 & 64 \\
\hline Potamopyrgus antipodon & 64 & 85 & 85 & - & 42 & 85 \\
\hline Arenomya arenaria (juv.) & 21 & - & 191 & 64 & - & - \\
\hline Hydrobia ulvae & - & 42 & 127 & 42 & - & - \\
\hline \multicolumn{7}{|l|}{ Crustacea } \\
\hline Cyathura carinata & 552 & 85 & - & - & - & - \\
\hline Idotea chelipes & 21 & - & - & - & - & - \\
\hline Corophium volutator & 21 & - & 997 & 42 & - & 64 \\
\hline \multicolumn{7}{|l|}{ Diptera (larvae) } \\
\hline Chironomidae & - & - & - & 318 & 10950 & 2292 \\
\hline Ceratopogonida & - & - & - & - & - & 64 \\
\hline Total abundance & 2715 & 7469 & 5729 & 3033 & 11353 & 2611 \\
\hline
\end{tabular}

and 2 were significantly higher than at Stns 3 and 4 $(\mathrm{p}<0.05)$. Chl a concentrations showed highest values in shallow-water sandy sediments $\left(7\right.$ to $39 \mu \mathrm{g} \mathrm{cm} \mathrm{cm}^{-3}$; Stns 3 and 4) and decreased steeply with increasing water depth and mud content. Relatively low chl a concentrations $\left(<8.3 \mu \mathrm{g} \mathrm{cm} \mathrm{cm}^{-3}\right)$ were measured in deeper, light-limited sandy and muddy sediments (Stns 1, 2, 5 and 6). Pheopigment concentrations (1 to $15 \mu \mathrm{g} \mathrm{cm}{ }^{-3}$ ) displayed a reverse pattern to chl a concentrations. An increasing accumulation of pheopigments was observed from nearshore to offshore sites. Stns 3 and 4 had significant lower pheopigment concentrations than Stns 5 and 6 (Kruskal-Wallis test; p < 0.05), and the latter were significantly different from pheopigment concentrations at Stns 1 and 2. Total bacterial numbers ranged between $0.62 \times 10^{9} \mathrm{~cm}^{-3}$ and $9.94 \times 10^{9} \mathrm{~cm}^{-3}$ and were close to the pattern previously described for phospholipids. Total bacterial numbers at Stns 3, 4, 5 and 6 were not different from each other, but significantly lower than at Stns 1 and 2 (Kruskal-Wallis test; $\mathrm{p}<0.05$ ).

\section{Enzymatic activity measurements}

Enzymatic activity rates of esterases (measured as FDA hydrolysis) were significantly lower in sandy sediments of Stns 3, 4, 5 and 6 (25 to $140 \mathrm{nmol} \mathrm{cm}^{-3} \mathrm{~h}^{-1}$ ) than in muddy sediments of Stns 1 and 2 (224 to $314 \mathrm{nmol} \mathrm{cm}^{-3} \mathrm{~h}^{-1}$, Kruskal-Wallis test: $\mathrm{p}<0.05)$, while the activity measured at the 4 sandy sites did not significantly differ ( $p>0.05$; Fig. 7a). $\beta$-D-glucosidase activity was enhanced at the sediment surface and displayed generally higher rates in muddy than in sandy sediments (Fig. 7b). $\alpha$-D-glucosidase activity was lower than $\beta$-D-glucosidase activity and barely differed in surface sediments among sites ( $p>0.05$; Fig. $7 \mathrm{c}$ ). Surprisingly, the sediment horizon 9 to $10 \mathrm{~cm}$ of Stn 6 with a mud content of $71 \%$ displayed a relatively low enzymatic activity of esterases, $\beta$-D-glucosidases and $\alpha$-D-glucosidases. Ratios of $\beta$-D-glucosidase to $\alpha$-D-glucosidase activity were extremely low in shallowwater sandy sediments (Stns 3 and 4), whereas significantly higher values were measured in subsurface sediment horizons of Stns 5 and 6 located on the slope, and in muddy surface sediments at Stn 2 in the central part of the GJB $(\mathrm{p}<0.05)$. 
Fig. 6. Concentrations $\mathrm{cm}^{-3}$ sediment of (a) phospholipids, (b) total bacterial numbers, (c) chlorophyll a (chl a), and (d) pheopigments in selected sediment horizons ( 0 to 1,4 to 5 , and 9 to $10 \mathrm{~cm}$ ) of 6 stations sampled in the GJB. Error bars: standard deviations of 5 to 6 parallel measurements

Fig. 7. Enzymatic activity $\mathrm{cm}^{-3}$ sediment of (a) esterases, (b) $\beta$-D-glucosidases and (c) $\alpha$-D-glucosidases measured as hydrolysis of model substrates fluorescein diacetate (FDA), methylumbelliferone- $\beta$-D-glucoside, methylumbelliferyl- $\alpha$-Dglucoside; (d) ratio of $\beta$-Dglucosidase activity to $\alpha$-Dglucosidase activity in selected sediment horizons (0 to 1,4 to 5,9 to $10 \mathrm{~cm}$ ) of 6 stations sampled in the GJB. Values are means of 3 parallel measurements
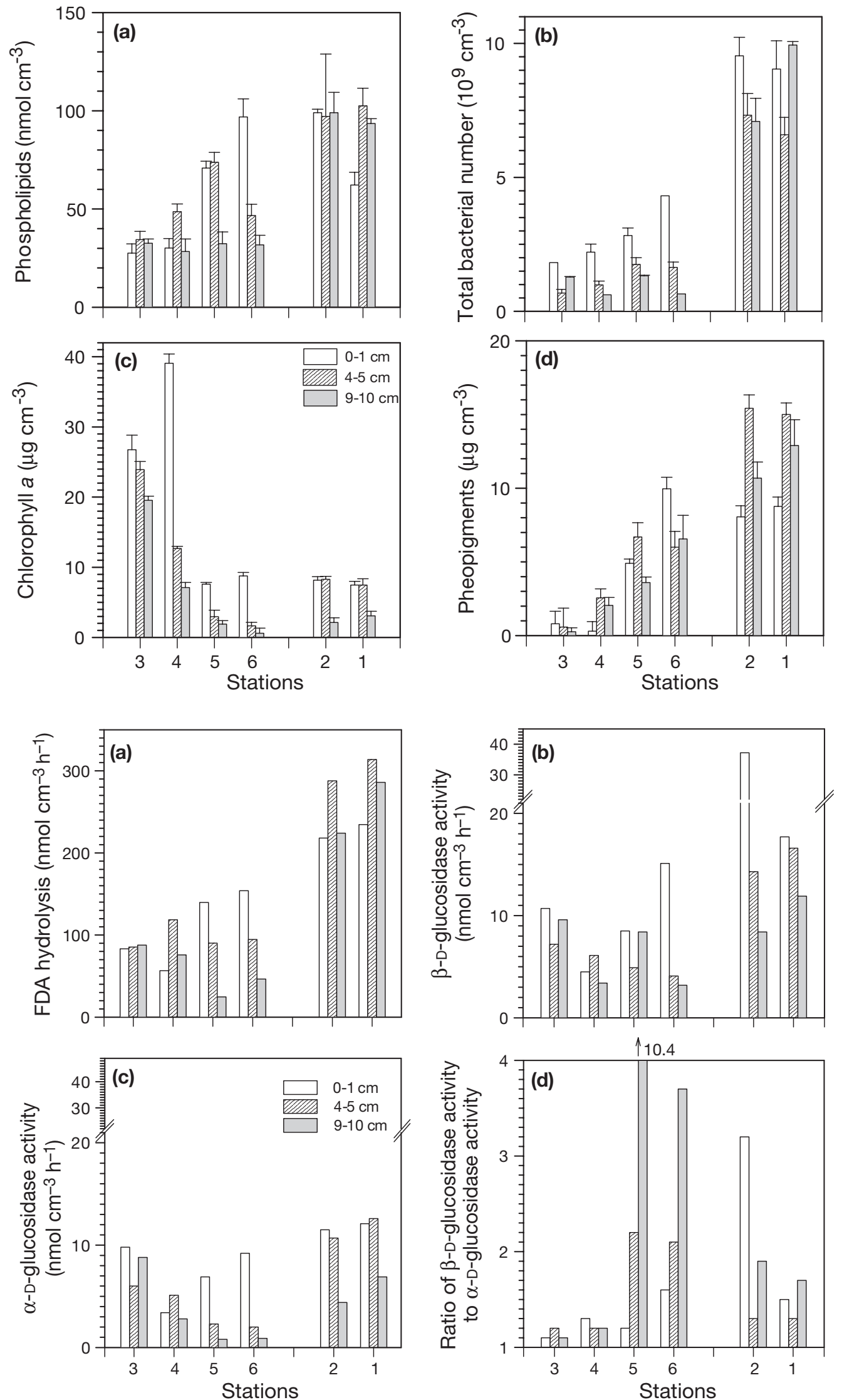


\section{DISCUSSION}

\section{Sediment characteristics and microbial colonization}

Sandy sediments in shallow waters of the hypertrophic GJB (Stns 3 and 4) displayed relatively low concentrations of inorganic and organic nutrients (Figs. 2, 3 $\& 5)$ and high lability of organic matter. The labile nature of organic matter was reflected by different indicators of degradability (low C:N ratio, high N:P ratio, high percentage of chl a (>50\%) to total chloropigments, and ratios of $\beta$-D-glucosidase activity to $\alpha$-D-glucosidase activity close to 1 ; Figs. 2, 3, 6 \& 7). In contrast, muddy sediments in the inner deeper regions (Stns 1 and 2) of the GJB were organic-rich accumulation sites influenced by high rates of phytoplankton production and deposition (Hübel et al. 1998), and probably by lateral sediment transport from shallow to deeper areas. Due to the storage of relatively high amounts of deposited organic matter, organic carbon and phosphorus became trapped in these sediments. The accumulation of highly degraded phytodetritus was indicated by high $\mathrm{C}: \mathrm{N}$ ratios as well as low $\mathrm{N}$ :P ratios, relatively large percentages of pheopigments ( $>50 \%$ ) to total chloropigments, and enhanced ratios of $\beta$-D-glucosidase activity to $\alpha$-D-glucosidase activity (1.3 to 3.6 ).

Sediment properties (e.g. grain size, quantity and degradability of organic nutrients, light penetration depth influence benthic microbial colonization (e.g. Dale 1974, deFlaun \& Mayer 1983, Meyer-Reil 1993), and benthic microorganisms, especially the microflora, alter sediment properties (e.g. erodibility; Miller et al. 1996, Decho et al. 2003). Not only micoorganisms, but also meio- and macrofauna affect sediment properties and stability considerably (e.g. Davis 1993, Bavestrello et al. 2000, Gutierrez et al. 2000, Berg et al. 2001). Sandy surficial sediments in shallow waters of the GJB (Stns 3 and 4) offered favorable light conditions for microphytobenthos (MPB) development. Relatively high values of photoautotrophic biomass based on chl a measurements (Fig. 6), and relatively high benthic primary production (Meyercordt pers. comm.) indicated that these sediments were highly productive (net autotrophic) environments in summer. Values for benthic microalgae biomass in sandy sediments of the hypertrophic GJB (Stns 3 and 4) ranged from 270 to

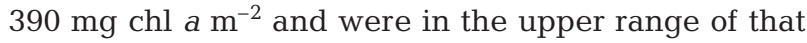
found for other microphytobenthic communities in estuarine sediments (cf. Meyercordt \& Meyer-Reil 1999). Significantly lower MPB biomass at Stn 3 than at Stn 4 may be the result of disturbance effects (e.g. water movement, resuspension, grazing; cf. Underwood \& Smith 1998) counteracting MPB colonization. With increasing water depth, light availability was the limiting factor suppressing MPB development. Thus, the significance of photoautotrophic organisms in sandy shallow-water sediments shifted to a dominance of heterotrophic organisms in muddy sediments of deeper waters (Stns 1 and 2).

Fig. 8 compiles data for all stations, revealing relationships between mud content, quantity and degradability of particulate organic matter (POM) and microbial biomass for different sediment types. Generally, concentrations of particulate organic compounds (C, N, $\mathrm{P}$ ) increased and organic matter degradability (indicated by $\mathrm{C}: \mathrm{N}$ ratio, N:P ratio, percentage of pheopigments, ratio of $\beta$-D-glucosidase activity to $\alpha$-D-glucosidase activity) decreased with increasing mud content until a certain 'threshold value' (mud content of 10\%) was reached. When the mud content exceeded a value of $10 \%$, increases in mud content were not associated with similar increases in organic matter concentrations and decreases in organic matter degradability (Fig. 8a to g). Similar results have been presented in earlier investigations (Köster \& Meyer-Reil 2001). Relating different indicators of organic matter degradability to each other, it became obvious that indicators respond in a different way to changes in organic matter quality. $\mathrm{C}: \mathrm{N}$ ratios and percentages of pheopigments to total chloropigments were closely related to each other in sandy and muddy sediments $(\mathrm{r}=0.857, \mathrm{n}=17$; $\mathrm{p}<$ 0.001; Fig. 8j), whereas relationships between C:N values and ratios of $\beta$-D-glucosidase-activity to $\alpha$-D-glucosidase activity were less pronounced $(\mathrm{r}=0.624, \mathrm{n}=$ 16; $\mathrm{p}<0.01$; Fig. 8k). However, a tighter relationship between the latter variables was attained when values of muddy sediments were exclusively considered. This might indicate that in fine-grained sediments a close coupling exists between the degradation status of refractory organic matter and the amount of $\beta$-D-glucosidases produced, whereas in sandy sediments the degradation of relatively labile organic matter does not essentially depend on the production of $\beta$-D-glucosidases. Parameters indicative of total microbial and bacterial biomass were similarily related to mud content (Fig. 8h,i) as previously described for indicators of quantity and degradability of POM.

\section{Significance of different organic carbon pools}

Pool sizes of TOC (calculated for an area of $1 \mathrm{~cm}^{2}$ down to a sediment depth of $10 \mathrm{~cm}$ ) were approximately 4-fold higher in muddy sediments at Stns 1 and 2 than in sandy sediments at Stns 3 and 4 (123.0 to $125.5 \mathrm{mg}$ and 27.6 to $29.8 \mathrm{mg}$ TOC cm $\mathrm{cm}^{-2} 10 \mathrm{~cm}^{-1}$, respectively). The significance of autotrophic and heterotrophic microorganisms in different sediments sampled was demonstrated by the contribution of different organic carbon fractions to TOC (Table 3). In the 

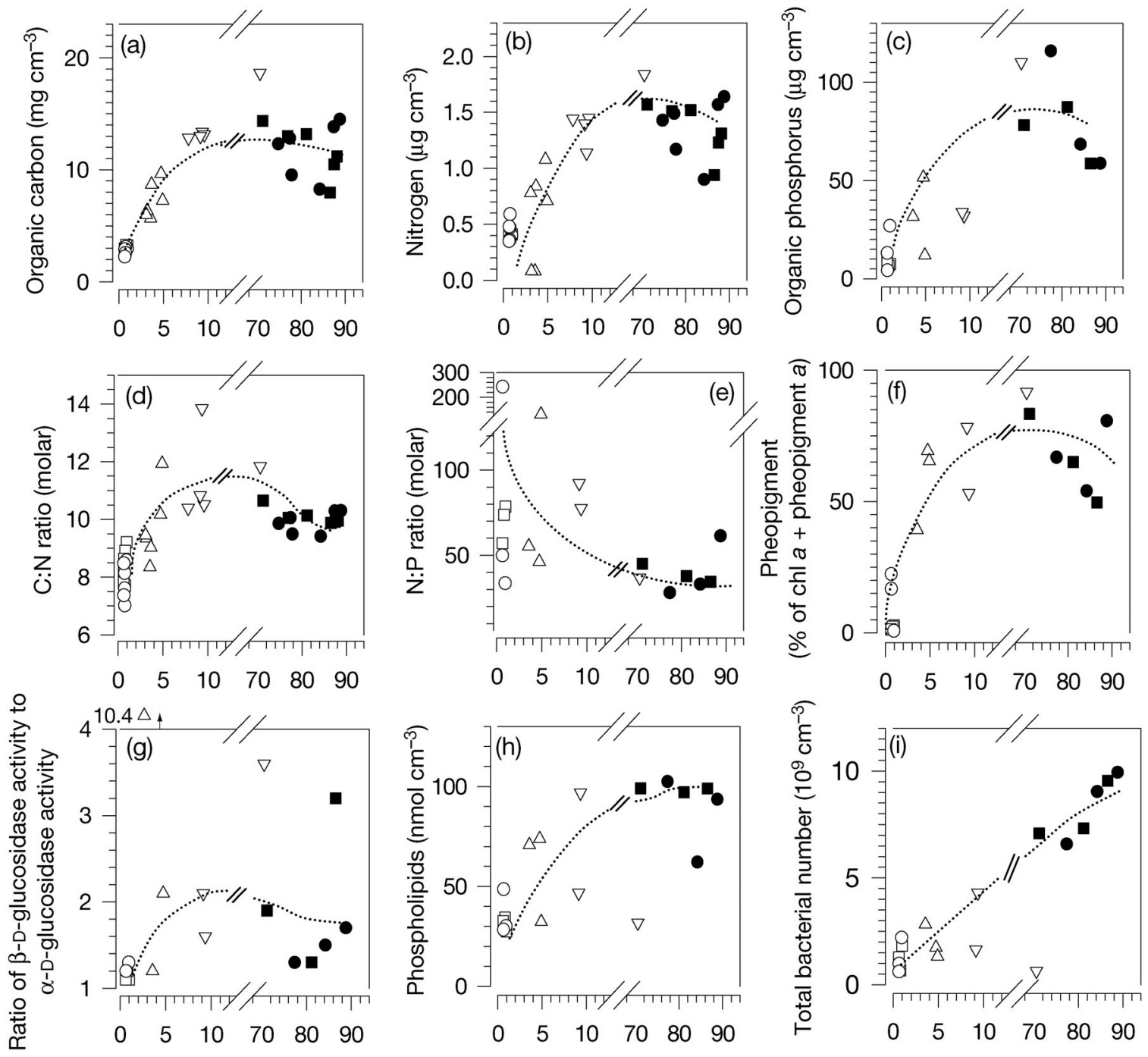

Sediment fraction $<63 \mu \mathrm{m}(\%)$

Sediment fraction $<63 \mu \mathrm{m}(\%)$

Sediment fraction $<63 \mu \mathrm{m}(\%)$
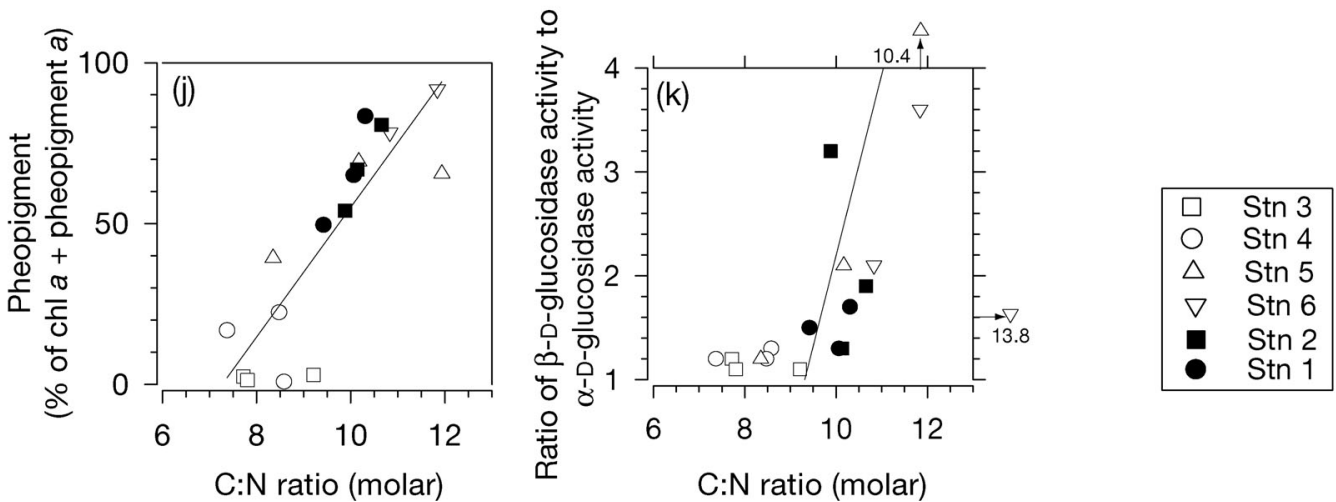

Fig. 8. Relationships between particulate organic matter, microbial biomass and mud content in sediments of 6 stations sampled in the GJB. Quantity and quality of organic matter were characterized by (a) organic carbon, (b) nitrogen, and (c) organic phosphorus, as well as by diverse indicators used to estimate organic matter degradability: (d) C:N ratio; (e) N:P ratio; (f) percentage of pheopigment $a_{i}(\mathrm{~g})$ ratio of $\beta$-D-glucosidase activity to $\alpha$-D-glucosidase activity. (h,i) Total microbial biomass and bacterial biomass indicated by phospholipid concentration and total bacterial number, respectively; dotted curves: trend lines. Note axis breaks separating sandy (open symbols) and muddy (filled symbols) sediments in (a) to (i). (j,k) Relationships between indicators of organic matter degradability (C:N ratio, percentage pheopigments, ratio of $\beta$-D-glucosidase activity to $\alpha$-D-glucosidase activity); continuous lines: regression curves, calculated using data from all stations (j), and data for Stns 1, 2, 5 and 6 (k) 
highly productive sandy surficial sediments $(0$ to $1 \mathrm{~cm})$, photoautotrophic biomass carbon (PBC) contributed from 33 to $52 \%$ of TOC. This value was relatively high compared to the $\mathrm{PBC}$ of other shallow estuary sands ( $\mathrm{PBC}=20 \%$ of TOC: Ferguson et al. 2003; PBC $=4$ to $11 \%$ of TOC: Köster \& Meyer-Reil 2001). In muddy sediments of the GJB, PBC accounted for only $4 \%$ of TOC, suggesting that mainly refractory particulate material associated with phytodetritus significantly contributed to its TOC. The percentage of bacterial biomass carbon (BBC) ranged from 0.9 to $1.3 \%$ of TOC and was slightly higher in muddy sediments than in sandy sediments. The shift in the $\mathrm{PBC}: \mathrm{BBC}$ ratio from 37 to 44 in sandy sediments down to 3 in muddy sediments indicated a pronounced predominance of benthic microalgae in the sandy sediments and a predominance of heterotrophic microorganisms in the muddy sediments of the accumulation sites.

Pool sizes of DOC were approximately 1.5-fold higher in sandy than in muddy sediments (143 to 207 and 92 to $140 \mu \mathrm{g} \mathrm{DOC} \mathrm{cm}{ }^{-2} 10 \mathrm{~cm}^{-1}$, respectively). DOC amounted to 0.6 to $1.0 \%$ of TOC in sandy sediments and decreased to $0.1 \%$ in muddy sediments. Common quantifications of DOC in aquatic systems usually include a high percentage of slowly degrading organic compounds. So far, only a small labile fraction of total DOC was thought to support microbial metabolism (e.g. Coffin et al. 1993), but now the use of a microbial biosensor has enabled us to determine the ecologically relevant fraction of ADOC, which includes different low molecular weight organic substrates (mainly monomeric and dimeric compounds) that are easily degradable and therefore rapidly taken up by microorganisms (e.g. Bertilsson \& Allard 1996). The concentration and composition of ADOC are influenced by the production and consumption of photosynthesis products (Coffin et al. 1993), substrates released by enzymatic and photochemical degradation of organic matter (Bertilsson \& Allard 1996, Taylor et al. 2003), assimilation of labile dissolved organic

Table 3. Contribution (\%) of different carbon fractions to total organic carbon in surface sediments $(0$ to $1 \mathrm{~cm})$ of sandy and muddy stations in the GJB. PBC: photoautotrophic biomass carbon; BBC: bacterial biomass carbon; DOC: dissolved organic carbon; ADOC: available dissolved organic carbon

\begin{tabular}{|lcc|}
\hline C fraction & $\begin{array}{c}\text { Sand } \\
\text { (Stns 3 and 4) }\end{array}$ & $\begin{array}{c}\text { Mud } \\
\text { (Stns 1 and 2) }\end{array}$ \\
\hline PBC & $33.0-52.4$ & $3.6-4.1$ \\
BBC & $0.9-1.2$ & $1.2-1.3$ \\
PBC:BBC ratio & $37-44$ & 3 \\
DOC & $0.6-1.0$ & 0.1 \\
ADOC & 0.16 & 0.01 \\
ADOC as \%DOC & $17-25$ & 6 \\
\hline
\end{tabular}

compounds by deposit-feeding invertebrates (Goedkoop et al. 1997), and processes such as bacterial excretion, leakage of phytoplankton, sloppy feeding and sorption to mineral surfaces (Keil et al. 1994). Several studies on the availability, reactivity and preservation of DOC (based on chemical analyses) have been performed in freshwater and marine waters (Amon \& Benner 1994, 1996, Burdige \& Gardner 1998, Gremm \& Kaplan 1998, Burdige 2001, Kaiser \& Sulzberger 2004). However, quantifications of microbially available carbon in porewaters of marine sediments are scarce (Nedwell 1987, Neudörfer \& Meyer-Reil 1997, Köster \& Meyer-Reil 2001), although needed to understand the carbon flux through microbial assemblages. In our study, the percentage of quantified ADOC accounted for 17 to $25 \%$ of DOC in the autotrophic-dominated sandy surface sediments (Stns 3 and 4) and for only $6.0 \%$ in the heterotrophic-dominated muddy surface sediments (Stn 2; Fig. 4, Table 3). Pool sizes of ADOC in sandy sediments of the GJB were about 10 times higher than those in muddy sediments. Positive relationships of ADOC to PBC ( $r=0.835, \mathrm{p}<0.05, \mathrm{n}=5$ ) and inverse relationships of ADOC to enzymatic degradation rates $(\mathrm{r}=0.852, \mathrm{p}<0.05, \mathrm{n}=5)$ in surface sediments indicate that labile organic matter was mainly supplied by the exudation of microalgae and the enzymatic hydrolysis of POM. A close coupling between enzymatic hydrolysis of polymeric material and consumption of a variety of monomeric products described for estuarine sediments of the Hudson river by Taylor et al. (2003) refer to an immediate uptake of ADOC by heterotrophic microorganisms. These findings underlie our assumption that the actual contribution of ADOC to total DOC fluxes could be higher than that quantified in pools because ADOC is microbially consumed faster than the remaining DOC, of which much is degraded slowly or is refractory.

\section{Interactions between microbial activity and porewater solutes}

At the sandy, organically poor Stns 3 and 4, the presence of microphytobenthos led to enhanced net oxygen production rates (59 to $68 \mathrm{mmol} \mathrm{O}_{2} \mathrm{~m}^{-2} \mathrm{~h}^{-1}$ measured at light saturation; Meyercordt pers. comm.) which exceeded net benthic oxygen demand by almost 1 order of magnitude, indicating that these sites were net photoautotrophic. Relatively high penetration depths of oxygen (several mm; Fig. 5a) and nitrate (several cm; Fig. 5c) due to microalgal photosynthetic activity and bioturbation of macrofauna (Table 2) indicated that these sediments were sources of oxygen and nitrate. At the same time, these sediments act as sinks of ammonium and phosphate through the assimilation of 
nutrients by microphytobenthos. Microbial enzymatic organic-matter degradation was relatively low in sandy sediments, probably due to a high amount of freshly produced, labile, dissolved organic material that was rapidly taken up by heterotrophic microorganisms.

Muddy depositional environments (Stns 1 and 2) in deeper waters of the GJB were characterized by an intensive microbial degradation of refractory organic matter, which was reflected in increased esterase activity in surface sediments that was about 2 to 4 times higher than that measured in sandy sediments (Fig. 7). Oxygen penetration depths in dark-incubated muddy sediments were reduced to less than $2.2 \mathrm{~mm}$ (Fig. 5b). Porewater profiles of phosphate and ammonium concentrations were characterized by strong gradients, indicating that these organically rich sediments were mainly sources of ammonium and phosphate (Fig. 5d,e).

\section{Comparison of sediments in eutrophic and hypertrophic waters}

Sediments of inner hypertrophic coastal waters (GJB) were compared to sediments of outer eutrophic coastal waters (Rassower Strom, RS) previously investigated by Köster \& Meyer-Reil (2001) to estimate how a different degree of eutrophication might influence structural and functional properties of sediments, size and composition of organic carbon pools, as well as microbial colonization and activity. In sandy shallowwater sediments (water depth less than $2 \mathrm{~m}$ ) of eutrophic and hypertrophic waters the pool sizes of TOC, DOC and ADOC were of comparable orders of magnitude. Differences in pool sizes of the differently eutrophicated sandy sediments became evident in PBC which was 3-fold higher in sandy sediments of the GJB than in sandy sediments of the RS. Additionally, the relative percentage of bacterial biomass to total microbial biomass was lower in sandy sediments of the hypertrophic GJB than in corresponding sediments of the eutrophic RS.

Differences in relationships between mud content, organic carbon concentrations, microbial biomass carbon and enzymatic activity might support a different functioning of sediments in environments of different trophic status. Sandy sediments of the hypertrophic GJB seemed to be more strongly loaded with organic carbon than sandy sediments with comparable mud contents in the eutrophic RS (Fig. 9a). Microbial enzymatic activity rates measured in hypertrophic sediments of the GJB increased slowly with increasing concentrations of organic carbon, whereas in sediments of the eutrophic RS enzymatic activity rapidly increased with increasing carbon concentrations (Fig. 9b). Enzymatic activity rates normalized to organic carbon concentrations were even 4- to 6-fold lower in sandy sediments of the GJB than in sandy sediments of the RS. Differences in carbon normalized enzymatic activity rates might primarily reflect differences in the composition and degradability of DOM. Different relationships found between $\mathrm{PBC}$ and $\mathrm{ADOC}$, and between enzymatic activity (esterase activity) and ADOC in surficial sediments of the inner and outer waters of the Nordrügensche Bodden underline the fact that the microbially available organic carbon in sediments of differently eutrophicated waters might be of different origin and composition, thus influencing the structure and functioning of microbial communities.
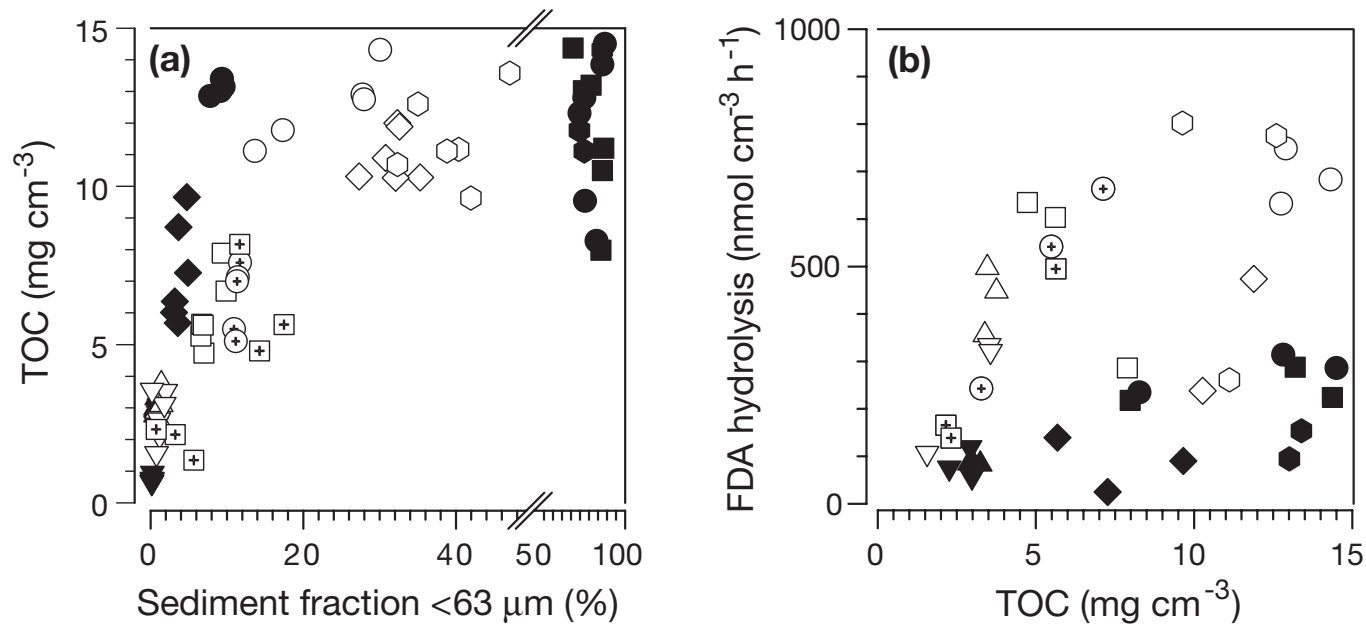

\begin{tabular}{|c|c|c|}
\hline $\mathrm{RS}$ & & GJB \\
\hline & $\begin{array}{l}= \\
-19.6^{\circ} \mathrm{C}\end{array}$ & $\begin{array}{l}T_{\mathrm{bw}}= \\
17.3-18.5^{\circ} \mathrm{C}\end{array}$ \\
\hline & $\begin{array}{l}\text { Stn } 3 \\
\text { Stn } 4\end{array}$ & $\begin{array}{l}\operatorname{Stn} 3 \\
\quad \operatorname{Stn} 4\end{array}$ \\
\hline$\stackrel{\square}{\oplus}$ & $\begin{array}{l}\text { Stn } 2 \\
\text { Stn } 7\end{array}$ & $\begin{array}{l}\text { Stn } 5 \\
\text { Stn } 6\end{array}$ \\
\hline$\boxplus$ & Stn 8 & \\
\hline $\begin{array}{l}0 \\
\diamond \\
0\end{array}$ & $\begin{array}{l}\text { Stn } 1 \\
\text { Stn } 5 \\
\text { Stn } 6\end{array}$ & 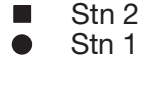 \\
\hline
\end{tabular}

Fig. 9. Relationships between (a) total organic carbon (TOC) and mud content, and (b) enzymatic activity (measured as FDA hydrolysis) and TOC in sediments of eutrophic and hypertrophic waters of the Nordrügensche Bodden ( $T_{\mathrm{bw}}$ : temperature of water overlying sediment). Open symbols: sites sampled in the eutrophic Rassower Strom (RS); filled symbols: stations sampled in the hypertrophic Großer Jasmunder Bodden (GJB). Station order in key corresponds to increasing mud content 


\section{CONCLUSIONS}

In essence, the results of our study indicate ecologically relevant interactions and relationships between sedimentary organic bulk parameters and the colonization and activity of the benthic microbial community in sandy and muddy hypertrophic coastal sediments of the Southern Baltic Sea. Whereas MPB is the driving force for metabolism in shallow-water sandy (net autotrophic) sediments, nutrient cycles are controlled by heterotrophic microbial processes at the deeper sites. Our findings revealed that sedimentary bulk parameters such as concentration and degradability of POM as well as microbial biomass and activity depend on mud content in pure sandy sediments (with a mud content $<10 \%$ ), while they remain unchanged in sediments with a mud content greater than $10 \%$. These findings imply that dissolved organic matter (accounting only for $<1 \%$ of total organic matter) and inorganic nutrients might be of much greater importance in regulating microbial biomass and activity than POM. To improve our understanding of the dynamics of the carbon pools, future research should evaluate the variability in concentration and composition of the ADOC pool, and short-term mechanisms responsible for temporally and spatially different fluxes of ADOC.

Acknowledgements. We thank the crew of the RV 'Professor F. Gessner' for their valuable assistance and support, Prof. Dr. B. W. Flemming (Senckenberg Institut, Wilhelmshaven) for the field work assistance, G. Lewin for analysing the macrofauna, and M. Gau, I. Kreuzer, B. Kuhlmann and W. Zenke for their valuable technical assistance. We are grateful to the thoughtful and helpful comments of 4 anonymous reviewers whose comments improved a previous version of the manuscript

\section{LITERATURE CITED}

Amon RMW, Benner R (1994) Rapid cycling of high-molecularweight dissolved organic matter in the ocean. Nature 369: 549-551

Amon RMW, Benner R (1996) Bacterial utilization of different size classes of dissolved organic matter. Limnol Oceanogr 41:41-51

Andersen JM (1976) An ignition method for the determination of total phosphorus in lake sediments. Water Res 10: 329-331

Anderson IC, McGlathery KJ, Tyler AC (2003) Microbial mediation of 'reactive' nitrogen transformations in a temporate lagoon. Mar Ecol Prog Ser 246:73-84

Aurada KD (2000) Hydrologische Aspekte der Bodden- und Haffgewässer. BODDEN 10:23-30

Baillie PW (1986) Oxygenation of intertidal estuarine sediments by benthic microalgal photosynthesis. Estuar Coast Shelf Sci 22:143-159

Banta GT, Holmer M, Jensen MH, Kristensen E (1999) Effects of two polychaete worms, Nereis diversicolor and Areni- cola marina, on aerobic and anaerobic decomposition in a sandy marine sediment. Aquat Microb Ecol 19:189-204

Bavestrello G, Bianchi CN, Calcinai B, Cattaneo-Vietti R, Cerrano C, Morri C, Puce S, Sara M (2000) Bio-mineralogy as a structuring factor for marine epibenthic communities. Mar Ecol Prog Ser 193:241-249

Berg P, Rysgaard S, Funch P, Sejr MK (2001) Effects of bioturbation on solutes and solids in marine sediments. Aquat Microb Ecol 26:81-94

Bertilsson S, Allard B (1996) Sequential photochemical and microbial degradation of refractory dissolved organic matter in a humic freshwater system. Arch Hydrobiol Spec Iss Adv Limnol 48:133-141

Bird DF, Duarte CM (1989) Bacteria-organic matter relationship in sediments: a case of spurious correlation. Can J Fish Aquat Sci 46:904-908

Black HJ, Dainat M, Köster M, Meyer-Reil LA (2002) A multiple corer for taking virtually undisturbed samples from shallow water sediments. Estuar Coast Shelf Sci 54:45-50

Burdige DJ (2001) Dissolved organic matter in Chesapeake Bay sediment pore waters. Org Geochem 32:487-505

Burdige DJ, Gardner KG (1998) Molecular weight distribution of dissolved organic carbon in marine sediment pore waters. Mar Chem 62:45-64

Cammen LM (1991) Annual bacterial production in relation to benthic microalgal production and sediment oxygen uptake in an intertidal sandflat and an intertidal mudflat. Mar Ecol Prog Ser 71:13-25

Cauwet G (1999) Determination of dissolved organic carbon and nitrogen by high temperature combustion. In: Grasshoff K, Kremling K, Ehrhardt M (eds) Methods of seawater analysis. Wiley-VCH, Weinheim, p 407-420

Christensen B, Vedel A, Kristensen E (2000) Carbon and nitrogen fluxes in sediment inhabited by suspension-feeding (Nereis diversicolor) and non-suspension-feeding (N. virens) polychaetes. Mar Ecol Prog Ser 192:203-217

Coffin RB, Connolly JP, Harris PS (1993) Availability of dissolved organic carbon to bacterioplankton examined by oxygen utilization. Mar Ecol Prog Ser 101:9-22

Conover WJ (1980) Practical nonparametric statistics. John Wiley \& Sons, New York

Dale NG (1974) Bacteria in intertidal sediments: factors related to their distribution. Limnol Oceanogr 19:509-518

Davis WR (1993) The role of bioturbation in sediment resuspension and its interaction with physical shearing. J Exp Mar Biol Ecol 171:187-200

Decho AW, Kawaguchi T, Allison MA, Louchard EM and 5 others (2003) Sediment properties influencing upwelling spectral reflectance signatures: the 'biofilm gel effect'. Limnol Oceanogr 48:431-443

deFlaun MF, Mayer LM (1983) Relationships between bacteria and grain surfaces in intertidal sediments. Limnol Oceanogr 28:873-881

Ferguson AJP, Eyre BD, Gay JM (2003) Organic matter and benthic metabolism in euphotic sediments along shallow sub-tropical estuaries, northern New South Wales, Australia. Aquat Microb Ecol 33:137-154

Findlay RH, King GM, Watling L (1989) Efficacy of phospholipid analysis in determining microbial biomass in sediments. Appl Environ Microbiol 55:2888-2893

Flemming BW (2000) A revised textural classification of gravel-free muddy sediments on the basis of ternary diagrams. Cont Shelf Res 20:1125-1137

Flemming BW, Delafontaine MT (2000) Mass physical properties of muddy intertidal sediments: some applications, misapplications and non-applications. Cont Shelf Res 20: 1179-1197 
Glud RN, Gundersen JK, Røy H, Jørgensen BB (2003) Seasonal dynamics of benthic $\mathrm{O}_{2}$ uptake in a semienclosed bay: importance of diffusion and faunal activity. Limnol Oceanogr 48:1265-1276

Goedkoop W, Gullberg KR, Johnson RK, Ahlgren I (1997) Microbial response of a freshwater benthic community to a simulated diatom sedimentation event: interactive efffects of benthic fauna. Microb Ecol 34:131-143

Grasshoff K, Kremling K, Ehrhardt M (1999) Methods of seawater analysis. Wiley-VCH, Weinheim

Gremm TJ, Kaplan LA (1998) Dissolved carbohydrate concentration, composition, and bioavailability to microbial heterotrophs in stream water. Acta Hydrochim Hydrobiol 26:167-171

Grenz C, Cloern JE, Hager SW, Cole BE (2000) Dynamics of nutrient cycling and related benthic nutrient and oxygen fluxes during a spring phytoplankton bloom in South San Francisco Bay (USA). Mar Ecol Prog Ser 197:67-80

Gutierrez D, Gallardo VA, Mayor S, Neira C and 6 others (2000) Effects of dissolved oxygen and fresh organic matter on the bioturbation potential of macrofauna in sublittoral sediments of Central Chile during the 1997/1998 El Niño. Mar Ecol Prog Ser 202:81-99

HELCOM (Helsinki Commission) (1988) Guidelines for the Baltic monitoring programme for the third stage. Baltic Sea Environ Proc 27D: biological determinants. Helsinki Commission, Helsinki, p 1-60

Hübel H, Wolff C, Meyer-Reil LA (1998) Salinity, inorganic nutrients, and primary production in a shallow coastal inlet in the Southern Baltic Sea (Nordrügensche Bodden) Results from long-term observations (1960-1989). Int Rev Hydrobiol 83:479-499

Hüttel M (1988) The impact of macrofauna on nutrient concentrations in pore water of intertidal sandflat sediments. Ber Inst Meereskd Kiel 182:203

Hüttel M (2002) Understanding the biocatalytic sand filter in the shelf. LOICZ Newsl 25:1-4

Hüttel M, Rusch A (2000) Transport and degradation of phytoplankton in permeable sediment. Limnol Oceanogr 45: 534-549

Kaiser E, Sulzberger B (2004) Phototransformation of riverine dissolved organic matter (DOM) in the presence of abundant iron: effect on DOM bioavailability. Limnol Oceanogr 49:540-554

Keil RG, Montlucon DB, Prahl FG, Hedges JI (1994) Sorptive preservation of labile organic matter in marine sediments. Nature 370:549-551

Kitlar J (1991) The impact of bioturbation on the transport of dissolved substances in pore water. Ber Inst Meereskd Kiel 210:111

Köster M, Meyer-Reil LA (2001) Characterization of carbon and microbial biomass pools in shallow water coastal sediments of the southern Baltic Sea (Nordrügensche Bodden). Mar Ecol Prog Ser 214:25-41

Köster M, Dahlke, S, Meyer-Reil LA (1997) Microbiological studies along a gradient of eutrophication in a shallow coastal inlet in the southern Baltic Sea (Nordrügensche Bodden). Mar Ecol Prog Ser 152:27-39

Kristensen E (1988) Benthic fauna and biogeochemical processes in marine sediments: microbial activities and

Editorial responsibility: Søren Rysgaard,

Silkeborg, Denmark fluxes. In: Blackburn TH, Sørensen J (eds) Nitrogen cycling in coastal marine environments. John Wiley \& Sons, New York, p 275-299

Magalhaes CM, Bordalo AA, Wiebe WJ (2002) Temporal and spatial patterns of intertidal sediment-water nutrient and oxygen fluxes in the Douro River estuary, Portugal. Mar Ecol Prog Ser 233:55-71

Meyercordt J, Meyer-Reil LA (1999) Primary production of benthic microalgae in two shallow coastal lagoons of different trophic status in the southern Baltic Sea. Mar Ecol Prog Ser 178:179-191

Meyer-Reil LA (1983) Benthic response to sedimentation events during autumn to spring at a shallow water station in the Western Kiel Bight. II. Analysis of benthic bacterial populations. Mar Biol 77:247-256

Meyer-Reil LA (1993) Mikrobielle Besiedlung und Produktion. In: Meyer-Reil LA, Köster M (eds) Mikrobiologie des Meeresbodens. Gustav Fischer Verlag, Jena, p 38-81

Meyer-Reil (1999) The Nordrügensche Boddengewässeraspects of microbial ecology of an unique environment. Arch Hydrobiol Spec Iss Adv Limnol 54:33-42

Miller DC, Geider RJ, MacIntyre HL (1996) Microphytobenthos: the ecological role of the 'secret garden' of unvegetated, shallow-water marine habitats. II. Role in sediment stability and shallow-water food webs. Estuaries 19: 202-212

Nedwell (1987) Distribution and pool sizes of microbially available carbon in sediment measured by a microbiological assay. FEMS Microbiol Ecol 45:47-52

Neudörfer F, Meyer-Reil LA (1997) A microbial biosensor for the microscale measurement of bioavailable organic carbon in oxic sediments. Mar Ecol Prog Ser 147:295-300

Precht E, Hüttel M (2003) Advective pore-water exchange driven by surface gravity wave and its ecological implications. Limnol Oceanogr 48:1674-1684

Reay WF, Gallagher DL, Simmons GM Jr (1995) Sedimentwater column oxygen and nutrient fluxes in nearshore environments of the lower Delmarva Peninsula, USA. Mar Ecol Prog Ser 118:215-227

Revsbech NP (1989) An oxygen microsensor with a guard cathode. Limnol Oceanogr 34:474-478

Smith DJ, Underwood GJC (2000) The production of extracellular carbohydrates by estuarine benthic diatoms: the effects of growth phase and light and dark treatment. J Phycol 36:321-333

Sundbäck K (1994) The response of shallow-water sediment communities to environmental changes. In: Krumbein E, Paterson DM, Stal LJ (eds) Biostabilization of sediments. Bibliotheks- und Informationssystem der Carl von Ossietzky Universität Oldenburg BIS-Verlag, Oldenburg, p 17-40

Sundbäck K, Miles A, Göransson E (2000) Nitrogen fluxes, denitrification and the role of microphytobenthos in microtidal shallow-water sediments: an annual study. Mar Ecol Prog Ser 200:59-76

Taylor GT, Way J, Yu Y, Scranton MI (2003) Ectohydrolase activity in surface waters of the Hudson River and western Long Island Sound estuaries. Mar Ecol Prog Ser 263:1-15

Underwood GJC, Smith DJ (1998) Predicting epipelic diatom exopolymer concentrations in intertidal sediments from sediment chlorophyll a. Microb Ecol 35:116-125

Submitted: May 1, 2004; Accepted: December 1, 2004

Proofs received from author(s): March 20, 2005 